\title{
Respon Pertumbuhan dan Hasil Jagung (Zea mays, L.) Varietas Pioner Terhadap Berbagai Takaran Pupuk Kandang Babi dan Jarak Tanam.
}

\author{
Maryanus A. Bhato \\ ${ }^{a}$ Fakultas Pertanian, Universitas Timor, Kefamenanu, TTU - NTT, 85613, Indonesia.
}

Article Info

Article histor

Received 14 September 2015

Received in revised form 20 September 2015 Accepted 18 Oktober 2015

\section{Keywords:}

Pupuk Kandang Babi

Jarak Tanam

Jagung

\begin{abstract}
Abstrak
Penelitian ini bertujuan untuk mengetahui pengaruh takaran pupuk kandang babi dan jarak tanam terhadap pertumbuhan dan hasil jagung hibrida varietas Pioner serta mengetahui takaran pupuk kandang babi dan jarak tanam yang tepat bagi pertumbuhan dan hasil jagung hibrida varietas Pioner yang optimum. Penelitian mengunakan Rancangan Acak Kelompok (RAK) faktorial 3 x 3 yang diulang tiga kali. Faktor pertama adalah takaran pupuk kandang babi yang terdiri dari tiga aras yaitu tanpa pupuk kandang babi, 20 t/ha dan 25 t/ha. Faktor kedua adalah jarak tanam yang terdiri dari tiga aras yaitu $70 \times 30 \mathrm{~cm}, 70 \times 40 \mathrm{~cm}$ dan $70 \times 50 \mathrm{~cm}$. Hasil penelitian menunjukan takaran pupuk kandang babi dan jarak tanam memberikan pengaruh interaksi terhadap panjang tongkol, berat 100 biji dan berat pipilan kering per petak. Takaran pupuk kandang babi berpengaruh nyata terhadap luas daun, panjang tongkol, diameter tongkol, jumlah biji per baris, berat pipilan kering per tanaman, berat pipilan kering per petak, berat segar berangkasan dan berat kering berangkasan. Jarak tanam berpengaruh nyata terhadap luas daun, jumlah baris per tongkol, jumlah tongkol per petak, berat pipilan kering per petak, berat segar berangkasan, berat kering berangkasan dan indeks panen. Takaran pupuk kandang babi $25 \mathrm{t} / \mathrm{ha}$ dengan jarak tanam $70 \mathrm{x} 30 \mathrm{~cm}$ memberikan hasil jagung tertinggi berupa pipilan kering 3,48 t/ha. (O2016 dipublikasikan oleh Savana Cendana.
\end{abstract}

\section{Pendahuluan}

Jagung merupakan salah satu jenis tanaman biji-bijian yang sudah populer di seluruh dunia. Berdasarkan sejarahnya, tanaman jagung berasal dari Amerika (Warisno, 1998). Menurut Rukmana (1997), di Indonesia, tanaman jagung dikenal sekitar 400 tahun lalu, didatangkan orang Portugis dan Spanyol.

Jagung adalah tanaman serealia yang bisa tumbuh hampir di seluruh dunia dan termasuk bahan pangan terpenting karena merupakan sumber karbohidra kedua setelah beras. Sebagai salah satu sumber bahan pangan, jagung telah menjadi komoditas utama setelah beras, bahkan di beberapa daerah di Indonesia jagung dijadikan sebagai bahan pangan utama pengganti beras atau sebagai campuran beras. Tanaman jagung banyak kegunanya, hampir seluruh bagian tanaman dapat dimanfaatkan untuk berbagai macam keperluan. Batang dan daun tanaman yang muda digunakan untuk pakan ternak. Batang dan daun tanaman yang tua (setelah dipanen) dapat digunakan sebagai pupuk hijau atau kompos. Di daerah sentra tanaman jagung, batang dan daun jagung yang kering digunakan untuk kayu bakar. Buah muda digunakan sebagai bahan sayuran, perkedel, bakwan dan sambal goreng. Biji jagung yang tua digunakan sebagai pengganti nasi, dibuat marning, brondong, roti (roti jagung), tepung dan sebagainya. Kegunaan lain jagung adalah sebagai bahan baku pembuatan pakan ternak dan industri bir, industri farmasi, dextrin termasuk untuk perekat dan industri tekstil (Purwono and Hartono, 2008).

Menurut Pingali (2001), komoditas jagung mempunyai peranan yang strategis dan ekomonis, dimana kebutuhan jagung terus meningkat sepanjan tahun. Pada tahun 2020, permintaan jagung di negara sedang berkembang diperkirakan akan melebihi permintaan beras dan gandum. Permintaan jagung dunia diperkirakan akan meningkat sebesar 50\%, yakni dari 558 juta ton pada tahun 1995 menjadi 837 juta ton pada tahun 2020. Sebaliknya menurut Marzuk (2002), produksi jagung bila dilihat secara nasional dari tahun ke tahun terjadi kecenderungan penurunan produksi. Data BPS RI (2014) menunjukkan pada tahun 2011 produksi jagung yaitu 17.643.250 ton, pada tahun 2012 meningkat menjadi 19.387.022 ton dan pada tahun 2013 produksi jagung menurun menjadi 18.506.287 ton

Pemupukan wajib dilakukan saat membudidayakan tanaman agar menggantikan unsur hara yang hilang. Untuk meningkatkan kuantitas maupun kualitas hasil jagung hibrida maka berbagai aspek budidaya harus diperhatikan Jagung memiliki sifat yang peka terhadap ketersediaan unsur hara sehingga aspek pemupukan dan jarak tanam yang tepat perlu diperhatikan.

Mahalnya harga pupuk anorganik serta pentingnya sistim pertanian berkelanjutan mengarahkan untuk pemanfaatan limbah organik yang murah, tersedia dan ramah lingkungan yang bisa digunakan sebagai pupuk organik seperti kotoran-kotoran hewan ternak seperti babi. Menurut Djajadiningrat dan Harsono (1991), seekor ternak setiap tahunnya menghasilkan feses sebanyak $20,2 \mathrm{~m}^{3}$. Hasil penelitian Ahmed et al., (2013) menunjukkan bahwa pemberian pupuk kandang babi meningkatkan hasil panen kedelai secara signifikan. Dalam proses pemupukan, perlu ditentukan takaran yang tepat sesuai kondis lingkungan dan tanaman yang akan dibudidayakan. Menurut Lingga dan Marsono (2001), tingginya dosis pemupukan untuk berbagai tanaman berbedabeda. Untuk mengetahui dosis yang tepat diperlukan data-data hasil percobaan. Dalam keadaan dimana hasil percobaan belum tersedia, dosis pupuk yan digunakan adalah dosis rekomendasi yaitu dosis pemupukan yang diberikan oleh balai-balai penelitian atau instansi yang berwenang.

Selain pemupukan, jarak tanam juga perlu diperhatikan dalam budidaya jagung. Menurut Effendi (1977), dalam suatu pertanaman sering terjad persaingan antar tanaman maupun antara tanaman dengan gulma untuk mendapatkan unsur hara, air, cahaya matahari maupun ruang tumbuh. Salah satu upaya yang dapat dilakukan untuk mengatasinya adalah dengan pengaturan jarak tanam. Djakfar et al., (1990) juga menambahkan bahwa jarak tanam merupakan faktor yang sangat penting dalam produksi tanaman. Walaupun jagung biasa ditanam lebih rapat, namun kompetisi antara tanaman meningkat tidak hanya dalam usaha mendapatkan air dan unsur hara, tetapi juga terhadap cahaya. Jarak yang optimum tergantung kepada faktor lingkungan serta genetik. Tetapi dua tanaman, biarpun saling dekat tumbuhnya tidak akan bersaing satu sama lainnya salama kandungan air, hara dan cahaya dalam keadaan cukup bag kebutuhan kedua tanaman itu, tetapi bila suatu ketika bahan itu menjadi kecil dari pada diperlukan maka akan tejadi persaingan.

Jarak tanam yang rapat akan meningkatkan daya saing tanaman terhadap gulma karena tajuk tanaman menghambat pancaran cahaya ke permukaan lahan sehingga pertumbuhan gulma menjadi terhambat, disamping juga laju evaporasi dapat ditekan (Dad Resiworo, 1992). Hasil penelitian Waluya (2009) menunjukkan jagung adalah tanaman yang efisien dalam penggunaan sarana tumbuh. Jarak tanam jagung yang dapat digunakan $80 \times 20 \mathrm{~cm}$ dan $80 \times 30 \mathrm{~cm}$. Yahya et al., (2005) menyatakan semakin tinggi populasi jagung yang ditumpangsarikan baik dengan varietas Arjuna, Pioner 4, maupun Cargil 9 mengakibatkan penurunan hasil umbi ubi kayu yang makin besar. Selanjutnya hasil penelitian Effendi, (2008) bahwa terjadi interaksi antara perlakuan jarak tanam dan defoliasi bunga jantan pada peubah diameter tongkol. Perlakuan kombinasi jarak tanam 70 × $20 \mathrm{~cm}$ dan defoliasi bunga jantan menunjukkan diameter tongkol yang lebih besar dibandingkan dengan kombinasi perlakuan lainnya.

Tanaman jagung tidak akan memberikan hasil maksimal jika unsur hara yang diperlukan tidak cukup tersedia. Pemupukan dapat meningkatkan hasi panen secara kuantitatif maupun kualitatif. Lingga dan Marsono, (2001) menyatakan bahwa, pupuk merupakan kunci dari kesuburan tanah karena beris satu atau lebih unsur untuk menggantikan unsur yang habis diserap tanaman. Penambahan pupuk kandang dikenal sebagai upaya terbaik dalam perbaikan level bahan organik dan humus.

Kandungan unsur hara dalam pupuk kandang babi setiap meter kubik adalah Nitrogen 4,2 $\mathrm{kg}$ dengan ketersediaan 35\%, fosfor $0,8 \mathrm{~kg}$ dengan ketersediaan $100 \%$. Hasil penelitian Kusuma, (2012) menunjukan bokhasi dari pupuk kandang babi memiliki kandungan $\mathrm{N}$ tertinggi dibanding dengan pupuk kandang sapi ayam dan kambing. Dosis umum pupuk kandang adalah antara 10 hingga 30 ton/ha.

Permasalahannya adalah belum diketahuinya takaran pupuk kandang babi dan jarak tanam yang tepat untuk mendapatkan pertumbuhan dan hasil jagung hibrida varietas Pioner yang optimum di wilayah Kabupaten Timor Tengah Utara (TTU). Penelitian ini bertujuan untuk mengetahui pengaruh takaran pupuk kandang babi dan jarak tanam terhadap pertumbuhan dan hasil jagung hibrida varietas Pioner serta mengetahui takaran pupuk kandang babi dan jarak tanam yang tepat bagi pertumbuhan dan hasil jagung hibrida varietas Pioner yang optimum.

\section{Metode}

2.1 Waktu dan Tempat

Penelitian ini dilaksanakan pada bulan Mei sampai September 2015 di Koko, Kelurahan Bansone, Kecamatan Kota Kefamenanu, Kabupaten TTU.

\subsection{Rancangan Percobaan}

Penelitian mengunakan Rancangan Acak Kelompok (RAK) faktorial 3 x 3 yang diulang tiga kali. Faktor pertama adalah takaran pupuk kandang babi $(\mathrm{P})$ yang terdiri dari tiga aras yaitu tanpa pupuk kandang babi $\left(\mathrm{p}_{0}\right), 20 \mathrm{t} / \mathrm{ha}\left(\mathrm{p}_{1}\right)$ dan $25 \mathrm{t} / \mathrm{ha}\left(\mathrm{p}_{2}\right)$. Faktor kedua adalah jarak tanam $(\mathrm{J})$ yang terdiri dari tiga aras yaitu $70 \times 30 \mathrm{~cm}\left(\mathrm{j}_{1}\right), 70 \times 40 \mathrm{~cm}\left(\mathrm{j}_{2}\right)$ dan $70 \times 50 \mathrm{~cm}\left(\mathrm{j}_{3}\right)$. Kombinasi perlakuannya antara lain $\mathrm{p}_{0} \mathrm{j}_{1}, \mathrm{p}_{0} \mathrm{j}_{2}, \mathrm{p}_{0} \mathrm{j}_{3}, \mathrm{p}_{1} \mathrm{j}_{1}, \mathrm{p}_{1} \mathrm{j}_{2}, \mathrm{p}_{1} \mathrm{j}_{3}, \mathrm{p}_{2} \mathrm{j}_{1}, \mathrm{p}_{2} \mathrm{j}_{2}$ dan $\mathrm{p}_{2} \mathrm{j}_{3}$

\subsection{Pelaksanaan Penelitian}

a. Persiapan Benih

Benih yang digunakan dalam penelitian ini adalah benih jagung hibrida varietas Pioner yang diambil dari Balai Benih Naibonat. Jumlah benih yan digunakan adalah 2.430 butir. Benih cadangan disiapkan $10 \%$ sehingga jumlah total benih yang disiapkan sebanyak 2.673 butir. 


\section{b. Pengolahan Tanah}

Tanah terlebih dahulu dibersihkan dari gulma dan serta vegetasi lainnya untuk selanjutnya dilakukan pengolahan. Pengolahan tanah dilakukan dengan menggunakan cangkul, kemudian dilanjutkan dengan penggemburan tanah. Lahan yang digunakan berukuran panjang $37,5 \mathrm{~m}$ dan lebar 12,5 $\mathrm{m}$ dengan luas $468,75 \mathrm{~m}^{2}$. Lahan dibagi dalam tiga blok dan pada masing-masing blok dibuat sembilan petak percobaan dengan ukuran 3,5 x 3,5 m dengan luas $12,25 \mathrm{~m}^{2}$ sehingga secara keseluruhan terdapat 27 petak. Jarak antara petak $0,5 \mathrm{~m}$ dan jarak antara blok $1 \mathrm{~m}$. Pada setiap blok, petak, tanaman sampel dan tanaman korban diberikan label menggunakan tiang bambu dan seng.

c. Aplikasi Pemupukan

Pupuk yang digunakan dalam penelitian ini adalah pupuk kandang yang berasal dari ternak babi yang telah mengalami pengomposan. Pemberian pupuk kandang babi dilakukan dengan cara pembenaman dalam tanah bersamaan dengan pengolahan tanah dengan takaran sesuai perlakuan. Pada sembilan petak percobaan tidak diberikan pupuk, sembilan petak percobaan diberikan dengan dosis $20 \mathrm{t} / \mathrm{ha}$ atau $24,5 \mathrm{~kg}$ per petak dan sembilan petak percobaan diberikan dengan dosis $25 \mathrm{t} / \mathrm{ha}$ atau $30,63 \mathrm{~kg}$ per petak. Total kebutuhan pupuk sebanyak 496,2 kg.

d. Penanaman

Penanaman dilakukan pada saat pagi hari, dengan cara tugal sedalam \pm 3 $\mathrm{cm}$. Jumlah benih yang ditanam per lubang adalah dua biji. Jarak tanam yang digunakan disesuaikan dengan perlakuan yakni pada sembilan petak ditanam menggunakan jarak tanam $70 \times 30 \mathrm{~cm}$ dengan jumlah tanaman setiap petak sebanyak 55 tanaman, sembilan petak ditanam menggunakan jarak tanam $70 \mathrm{x}$ $40 \mathrm{~cm}$ dengan jumlah tanaman setiap petak sebanyak 45 tanaman dan sembilan petak ditanam menggunakan jarak tanam 70 x $50 \mathrm{~cm}$ dengan jumlah tanaman setiap petak sebanyak 35 tanaman. Jumlah tanaman keseluruhan sebanyak 1.215 tanaman.

e. Pemeliharaan

Pemeliharaan tanaman meliputi penyiraman, penyulaman, penyiangan serta pengendalian hama dan penyakit tanaman. Penyiraman dilakukan pada pagi dan sore hari hingga tanah cukup basah dengan menggunakan selang atau ember. Penyiraman dilakukan hingga tanaman berumur 1-2 bulan, pada periode pembentukkan dan perkembangan buah, yaitu umur 2-3 minggu sebelum panen, penyiraman dikurangi. Penyulaman dilakukan apabila ada tanaman yang tidak tumbuh atau mati. Penyiangan dilakukan apabila ada gulma yang tumbuh agar tidak mengganggu pertumbuhan tanaman jagung. Pengendalian hama dan penyakit dilakukan apabila tanaman mengalami serangan hama dan penyakit.

\section{f. Panen}

Panen jagung dilakukan dengan kriteria tongkol atau klobot sudah mengering, biji mengkilap, keras dan bila ditekan dengan kuku tidak membekas serta terlihat ada lapisan hitam (black layer) pada bagian pangkal biji yang menempel pada tongkol. Panen dilakukan saat umur tanaman jagung 90 hari setelah tanam (HST).

\subsection{Parameter Pengamatan}

a. Tinggi Tanaman $(\mathrm{cm})$

Tinggi tanaman diukur dengan cara daun ditegakkan, diukur dari pangkal batang sampai daun paling tinggi, pengukuran menggunakan penggaris centimeter. Pengukuran dilakukan pada lima tanaman sampel saat berumur 14 HST, 35 HST dan 56 HST.

b. Diameter Batang $(\mathrm{cm})$

Diameter batang diukur menggunakan jangka sorong dengan cara menjepit pada bagian batang $(2 \mathrm{~cm}$ di atas pangkal batang) dari lima tanaman sampel. Pengukuran dilakukan pada saat tanaman berumur 14 HST, 35 HST dan 56 HST.

c. Luas Daun $\left(\mathrm{cm}^{2}\right)$

Luas daun diukur pada saat tanaman mencapai pertumbuhan vegetatif maksimum (56 HST) menggunakan metode fotografi dengan cara mengambil semua daun pada tiga tanaman korban setiap petak, kemudian daun dipotret menggunakan kamera digital. Luas area daun kemudian dihitung menggunakan program ImageJ versi 1.410 .

d. Jumlah Tongkol Per Tanaman

Diukur dengan cara menghitung tongkol yang dihasilkan setiap tanaman pada lima tanaman sampel.

e. Panjang Tongkol $(\mathrm{cm})$

Panjang tongkol diukur pada semua bulir yang terbentuk dari lima tanaman sampel kemudian dirata-ratakan. Penggukuran panjang tongkol menggunakan mistar $30 \mathrm{~cm}$, dan diukur dari pangkal hingga ujung tongkol.

f. Diameter Tongkol $(\mathrm{cm})$

Pengukuran diameter tongkol dilakukan pada semua tongkol yang terbentuk dari lima tanaman sampel kemudian dirata-ratakan. Pengukuran diameter tongkol menggunakan jangka sorong pada pangkal, tenggah dan ujung setiap tongkol.

g. Jumlah Baris Per Tongkol

Jumlah baris per tongkol diperoleh dengan cara menghitung barisan biji yang terdapat pada setiap tongkol tanaman sampel kemudian dirata-ratakan. h. Jumlah Biji Per Baris

Jumlah biji per baris diperoleh dengan cara menghitung semua biji dalam baris pada setiap tongkol tanaman sampel kemudian dirata-ratakan. i. Jumlah Tongkol Per Petak

Diukur dengan cara menghitung tongkol yang dihasilkan tanaman pada setiap petak kemudian dikonversikan ke jumlah tongkol per hektar.

j. Berat Pipilan Kering Per Tanaman (g)

Berat pipilan kering per tanaman diperoleh dengan cara menimbang semua biji dari lima tanaman sampel pada setiap petak yang telah dijemur selama satu minggu.

k. Berat 100 Biji (g)

Diukur dangan cara menimbang 100 biji yang diambil secara acak dari setiap petak yang telah dijemur selama satu minggu. Penimbangan dilakukan tiga kali kemudian dirata-ratakan.

1. Berat Pipilan Kering Per Petak (t/ha)

Berat pipilan kering per petak diperoleh dengan cara menimbang semua biji pada setiap petak yang telah dijemur selama satu minggu kemudian dikonversikan ke satuan $\mathrm{t} / \mathrm{ha}$.

m. Berat Segar Berangkasan(t/ha)

Berat segar berangkasan diukur dengan cara menimbang berangkasan segar semua tanaman dalam setiap petak yang telah dipanen dan kemudian dikonversikan ke satuan t/ha.

n. Berat Kering Berangkasan(t/ha)

Berat kering berangkasan diukur dengan cara menimbang berangkasan semua tanaman dalam setiap petak yang telah dipanen dan dijemur selama satu minggu kemudian dikonversikan ke satuan t/ha.

o. Indeks Panen (\%)

Indeks panen dihitung dengan cara membandingkan berat bagian tanaman yang bernilai ekonomis dengan berat bagian seluruh tanaman kemudian dikonversikan ke satuan \%. Indeks panen dihitung dengan rumus (Joses, 1997):

$$
\begin{array}{cl} 
& \mathrm{IP}=\frac{\mathrm{A}}{\mathrm{A}+\mathrm{B}} \mathrm{X} 100 \% \\
\text { Keterangan } & : \text { Indeks Panen (\%) } \\
\text { IP } & : \text { Berat Kering Pipilan Per Petak (t/ha) } \\
\text { A } & : \text { Berat Kering Brangkasan(t/ha) }
\end{array}
$$

\subsection{Analisis Data}

Data hasil pengamatan kemudian dianalisis dengan menggunakan sidik ragam (Anova) Rancangan Acak Kelompok (RAK). Rata-rata perlakuan selanjutnya diuji lanjut dengan menggunakan Duncan Multiple Range Test (DMRT) dengan tingkat signifikasi 5\% sesuai petunjuk (Gomez dan Gomez, 1984). Analisis data dengan menggunakan program SAS 9.1

\section{Hasil dan Pembahasan}

\subsection{Tinggi Tanaman}

Tanaman terus bertambah tinggi sejak awal pertumbuhan hingga waktu pengukuran terakhir dengan laju pertumbuhan yang lebih tinggi pada periode pengukuran 35 HST hingga 56 HST. Hasil sidik ragam (Anova) menunjukkan bahwa tidak terjadi pengaruh interaksi antara takaran pupuk kandang babi dan jarak tanam terhadap tinggi tanaman. Takaran pupuk kandang babi dan jarak tanam juga tidak memberikan pengaruh utama masing-masing perlakuan terhadap tinggi tanaman setiap waktu pengamatan. Meskipun demikian, data Tabel 1. menunjukkan bahwa tanaman yang diberikan pupuk kandang babi dengan takaran 25 t/ha cenderung lebih tinggi pada pertumbuhan 14 HST tetapi pada pengamatan 35 HST dan 56 HST tanaman yang diberikan pupuk kandang babi dengan takaran 20 t/ha cenderung lebih tinggi, sebaliknya tanaman yang diberikan pupuk kandang babi dengan takaran 25 t/ha paling pendek.

Tanaman yang ditanam dengan jarak $70 \times 30 \mathrm{~cm}$ cenderung lebih tinggi saat 14 HST hingga 35 HST sedangkan tanaman yang ditanam dengan jarak 70 x $50 \mathrm{~cm}$ paling pendek. Sebaliknya pada pengamatan $56 \mathrm{HST}$, tanaman yang ditanam dengan jarak $70 \times 50 \mathrm{~cm}$ cenderung lebih tinggi sedangkan tanaman yang ditanam dengan jarak $70 \times 30 \mathrm{~cm}$ paling pendek.

Tabel 1. Tinggi Tanaman $(\mathrm{cm})$

\begin{tabular}{cccccc}
\hline Waktu & Takaran & \multicolumn{3}{c}{ Jarak Tanam } & \multirow{2}{*}{ Rerata } \\
\cline { 3 - 5 } Pengamatan & Pupuk & $70 \times 30$ & $70 \times 40$ & $70 \times 50$ & \\
\hline \multirow{3}{*}{$14 \mathrm{HST}$} & $0 \mathrm{t} / \mathrm{ha}$ & 30,0 & 26,8 & 25,3 & $27,4 \mathrm{a}$ \\
& $20 \mathrm{t} / \mathrm{ha}$ & 28,4 & 27,9 & 28,5 & $28,3 \mathrm{a}$ \\
& $25 \mathrm{t} / \mathrm{ha}$ & 30,5 & 30,8 & 29,1 & $30,1 \mathrm{a}$ \\
\cline { 2 - 5 } & Rerata & $29,6 \mathrm{a}$ & $28,5 \mathrm{a}$ & $27,6 \mathrm{a}$ & $(-)$ \\
\hline \multirow{3}{*}{$35 \mathrm{HST}$} & $0 \mathrm{t} / \mathrm{ha}$ & 83,6 & 76,7 & 66,0 & $75,4 \mathrm{a}$ \\
& $20 \mathrm{t} / \mathrm{ha}$ & 78,2 & 77,7 & 77,7 & $77,9 \mathrm{a}$ \\
& $25 \mathrm{t} / \mathrm{ha}$ & 71,6 & 75,6 & 73,6 & $73,6 \mathrm{a}$ \\
\cline { 2 - 5 } $56 \mathrm{HST}$ & Rerata & $77,8 \mathrm{a}$ & $76,7 \mathrm{a}$ & $72,4 \mathrm{a}$ & $(-)$ \\
& $0 \mathrm{t} / \mathrm{ha}$ & 146,6 & 145,1 & 132,3 & $141,3 \mathrm{a}$ \\
& $20 \mathrm{t} / \mathrm{ha}$ & 134,1 & 140,3 & 154,2 & $142,9 \mathrm{a}$ \\
& $25 \mathrm{t} / \mathrm{ha}$ & 136,2 & 141,4 & 141,0 & $139,6 \mathrm{a}$ \\
\hline & Rerata & $139,0 \mathrm{a}$ & $142,3 \mathrm{a}$ & $142,5 \mathrm{a}$ & $(-)$ \\
\hline
\end{tabular}

Keterangan: Angka pada baris dan kolom yang diikuti dengan huruf yang sama tidak berbeda nyata menurut uji DMRT $\alpha 5 \%$

$(-)$ : Tidak terjadi interaksi antar factor 


\subsection{Diameter Batang}

Batang tanaman terus bertambah besar sejak awal pertumbuhan hingga waktu pengukuran terakhir dengan laju pertambahan ukuran diameter yang lebih tinggi pada periode pengukuran 14 HST hingga 35 HST. Hasil sidik ragam (Anova) menunjukkan bahwa tidak terjadi pengaruh interaksi antara takaran pupuk kandang babi dan jarak tanam terhadap diameter batang. Takaran pupuk kandang babi dan jarak tanam juga tidak memberikan pengaruh utama masing-masing perlakuan terhadap diameter batang tanaman setiap waktu pengamatan. Meskipun demikian, data Tabel 2. menunjukkan bahwa batang tanaman yang diberikan pupuk kandang babi dengan takaran 20 t/ha maupun 25 t/ha cenderung lebih besar pada pertumbuhan 14 HST dan 35 HST dan pada pengamatan 56 HST batang tanaman yang diberikan pupuk kandang babi dengan takaran $25 \mathrm{t} / \mathrm{ha}$ cenderung lebih besar dibandingkan batang tanaman yang tidak diberikan pupuk kandang babi maupun yang diberikan pupuk kandang babi dengan takaran 20 t/ha

Batang tanaman yang ditanam dengan jarak $70 \times 50 \mathrm{~cm}$ cenderung lebih besar saat 14 HST dan 56 HST dibandingkan batang tanaman yang ditanam dengan jarak $70 \times 30 \mathrm{~cm}$ maupun $70 \times 40 \mathrm{~cm}$, sebaliknya pada saat 35 HST batang tanaman yang ditanam dengan jarak $70 \times 30 \mathrm{~cm}$ dan $70 \times 40 \mathrm{~cm}$ cenderung lebih besar dibandingkan batang tanaman yang ditanam dengan jarak $70 \times 50 \mathrm{~cm}$.

Tabel 2. Diameter Batang (cm)

\begin{tabular}{cccccc}
\hline Waktu & Takaran & \multicolumn{3}{c}{ Jarak Tanam } & \multirow{2}{*}{ Rerata } \\
\cline { 3 - 5 } Pengamatan & Pupuk & $70 \times 30$ & $70 \times 40$ & $70 \times 50$ & \\
\hline \multirow{4}{*}{$14 \mathrm{HST}$} & $0 \mathrm{t} / \mathrm{ha}$ & 0,3 & 0,3 & 0,3 & $0,3 \mathrm{a}$ \\
& $20 \mathrm{t} / \mathrm{ha}$ & 0,3 & 0,3 & 0,4 & $0,4 \mathrm{a}$ \\
& $25 \mathrm{t} / \mathrm{ha}$ & 0,4 & 0,4 & 0,4 & $0,4 \mathrm{a}$ \\
\cline { 2 - 5 } & Rerata & $0,3 \mathrm{a}$ & $0,3 \mathrm{a}$ & $0,4 \mathrm{a}$ & $(-)$ \\
\hline \multirow{3}{*}{$35 \mathrm{HST}$} & $0 \mathrm{t} / \mathrm{ha}$ & 1,4 & 1,4 & 1,2 & $1,3 \mathrm{a}$ \\
& $20 \mathrm{t} / \mathrm{ha}$ & 1,4 & 1,3 & 1,5 & $1,4 \mathrm{a}$ \\
& $25 \mathrm{t} / \mathrm{ha}$ & 1,3 & 1,4 & 1,4 & $1,4 \mathrm{a}$ \\
\cline { 2 - 5 } & Rerata & $1,4 \mathrm{a}$ & $1,4 \mathrm{a}$ & $1,3 \mathrm{a}$ & $(-)$ \\
\hline \multirow{5}{*}{$56 \mathrm{HST}$} & $0 \mathrm{t} / \mathrm{ha}$ & 1,5 & 1,5 & 1,5 & $1,5 \mathrm{a}$ \\
& $20 \mathrm{t} / \mathrm{ha}$ & 1,5 & 1,5 & 1,6 & $1,5 \mathrm{a}$ \\
& $25 \mathrm{t} / \mathrm{ha}$ & 1,5 & 1,6 & 1,6 & $1,6 \mathrm{a}$ \\
\cline { 2 - 5 } & Rerata & $1,5 \mathrm{a}$ & $1,5 \mathrm{a}$ & $1,6 \mathrm{a}$ & $(-)$ \\
\hline
\end{tabular}

Keterangan: Angka pada baris dan kolom yang diikuti dengan huruf yang sama tidak berbeda nyata menurut uji DMRT $\alpha 5 \%$

$(-)$ : Tidak terjadi interaksi antar faktor

\subsection{Luas Daun}

Hasil sidik ragam (Anova) menunjukkan bahwa tidak terjadi pengaruh interaksi antara takaran pupuk kandang babi dan jarak tanam terhadap luas daun. Takaran pupuk kandang babi dan jarak tanam memberikan pengaruh utama masing-masing perlakuan terhadap luas daun. Permukaan daun tanaman yang tidak diberikan pupuk kandang babi paling luas dan berbeda nyata dengan luas daun tanaman yang diberikan pupuk kandang babi dengan takaran $20 \mathrm{t} / \mathrm{ha}$ maupun 25 t/ha yang memiliki permukaan daun paling sempit. Tanaman yang ditanam dengan jarak $70 \times 40 \mathrm{~cm}$ memiliki permukaan daun yang paling luas dan berbeda nyata dengan luas daun tanaman yang ditanam dengan jarak $70 \mathrm{x}$ $30 \mathrm{~cm}$ tetapi tidak berbeda nyata dengan luas daun tanaman yang ditanam dengan jarak 70 × $50 \mathrm{~cm}$.

Tabel 3. Luas Daun $\left(\mathrm{cm}^{2}\right)$

\begin{tabular}{ccccc}
\hline Takaran & \multicolumn{3}{c}{ Jarak Tanam } & \multirow{2}{*}{ Rerata } \\
\cline { 2 - 4 } Pupuk & $70 \times 30$ & $70 \times 40$ & $70 \times 50$ & \\
\hline $0 \mathrm{t} / \mathrm{ha}$ & 1484,9 & 2766,3 & 2374,8 & $2208,7 \mathrm{a}$ \\
$20 \mathrm{t} / \mathrm{ha}$ & 1289,3 & 1838,8 & 1323,9 & $1484,0 \mathrm{~b}$ \\
$25 \mathrm{t} / \mathrm{ha}$ & 1210,3 & 1456,2 & 1275,7 & $1314,1 \mathrm{~b}$ \\
\hline Rerata & $1328,1 \mathrm{~b}$ & $2020,4 \mathrm{a}$ & $1658,1 \mathrm{ab}$ & $(-)$ \\
\hline Keterangan : & $\begin{array}{l}\text { Angka pada baris dan kolom yang diikuti dengan huruf } \\
\text { tidak berbeda nyata menurut uji DMRT } \alpha 5 \%\end{array}$ & \\
& (-) : Tidak terjadi interaksi antar faktor &
\end{tabular}

\subsection{Jumlah Tongkol Per Tanaman}

Setiap tanaman yang dibudidayakan dalam penelitian ini menghasilkan dua buah tongkol dimana masing-masing individu tanaman menghasilkan satu tongkol sehingga dapat dikatakan bahwa takaran pupuk kandang babi dan jarak tanam tidak memberikan pengaruh terhadap jumlah tongkol per tanaman, baik pengaruh interaksi maupun pengaruh utama masing-masing perlakuan.

Tabel 4. Jumlah Tongkol Per Tanaman

\begin{tabular}{ccccc}
\hline Takaran & \multicolumn{3}{c}{ Jarak Tanam } & \multirow{2}{*}{ Rerata } \\
\cline { 2 - 4 } Pupuk & $70 \times 30$ & $70 \times 40$ & $70 \times 50$ & \\
\hline $0 \mathrm{t} / \mathrm{ha}$ & 2 & 2 & 2 & 2 \\
$20 \mathrm{t} / \mathrm{ha}$ & 2 & 2 & 2 & 2 \\
$25 \mathrm{t} / \mathrm{ha}$ & 2 & 2 & 2 & 2 \\
\hline Rerata & 2 & 2 & 2 & \\
\hline
\end{tabular}

\subsection{Panjang Tongkol}

Hasil sidik ragam (Anova) menunjukkan bahwa takaran pupuk kandang babi dan jarak tanam memberikan pengaruh interaksi terhadap panjang tongkol dimana tongkol dari tanaman yang diberikan pupuk kandang babi dengan takaran $25 \mathrm{t} / \mathrm{ha}$ dan ditanam dengan jarak $70 \times 30 \mathrm{~cm}$ paling panjang dan berbeda nyata dengan panjang tongkol yang dihasilkan tanaman yang tidak diberikan pupuk kandang babi pada semua level jarak tanam serta panjang tongkol dari tanaman yang diberikan pupuk kandang babi dengan takaran 20 t/ha dan ditanam dengan jarak $70 \times 40 \mathrm{~cm}$, tetapi tidak berbeda nyata dengan panjang tongkol yang dihasilkan oleh tanaman yang mendapat kombinasi perlakuan lainnya.

Takaran pupuk kandang babi memberikan pengaruh utama terhadap panjang tongkol. Tongkol yang dihasilkan dari tanaman yang diberikan pupuk kandang babi dengan takaran 25 t/ha paling panjang dan berbeda nyata dengan panjang tongkol yang dihasilkan dari tanaman yang tidak diberikan pupuk kandang babi tetapi tidak berbeda nyata dengan panjang tongkol yang dihasilkan dari tanaman yang diberikan pupuk kandang babi dengan takaran 20 t/ha. Jarak tanam tidak memberikan pengaruh utama terhadap panjang tongkol tetapi data Tabel 5. menunjukkan bahwa tanaman yang ditanam dengan jarak $70 \times 30 \mathrm{~cm}$ menghasilkan tongkol yang cenderung lebih panjang sedangkan tanaman yang ditanam dengan jarak 70 x $40 \mathrm{~cm}$ menghasilkan tongkol yang paling pendek.

\section{Tabel 5. Panjang Tongkol $(\mathrm{cm})$}

\begin{tabular}{ccccc}
\hline Takaran & \multicolumn{3}{c}{ Jarak Tanam } & \multirow{2}{*}{ Rerata } \\
\cline { 2 - 4 } Pupuk & $70 \times 30$ & $70 \times 40$ & $70 \times 50$ & \\
\hline $0 \mathrm{t} / \mathrm{ha}$ & $10,8 \mathrm{~d}$ & $11,9 \mathrm{~cd}$ & $11,5 \mathrm{~cd}$ & $11,4 \mathrm{~b}$ \\
$20 \mathrm{t} / \mathrm{ha}$ & $13,6 \mathrm{a}$ & $12,3 \mathrm{bc}$ & $13,3 \mathrm{ab}$ & $13,1 \mathrm{a}$ \\
$25 \mathrm{t} / \mathrm{ha}$ & $14,0 \mathrm{a}$ & $12,8 \mathrm{abc}$ & $12,8 \mathrm{abc}$ & $13,2 \mathrm{a}$ \\
\hline Rerata & $12,8 \mathrm{a}$ & $12,3 \mathrm{a}$ & $12,5 \mathrm{a}$ & $(+)$ \\
\hline Keterangan : & $\begin{array}{l}\text { Angka pada baris dan kolom yang diikuti dengan huruf } \\
\end{array}$ & tidak berbeda nyata menurut uji DMRT $\alpha 5 \%$ & \\
& $(+)$ : Terjadi interaksi antar faktor &
\end{tabular}

\subsection{Diameter Tongkol}

Hasil sidik ragam (Anova) menunjukkan bahwa tidak terjadi pengaruh interaksi antara takaran pupuk kandang babi dan jarak tanam terhadap diameter tongkol. Takaran pupuk kandang babi memberikan pengaruh utama terhadap diameter tongkol dimana tongkol yang dihasilkan dari tanaman yang diberikan pupuk kandang babi dengan takaran 20 t/ha dan 25 t/ha paling besar dan berbeda nyata dengan diameter tongkol yang dihasilkan dari tanaman yang tidak diberikan pupuk kandang babi. Jarak tanam tidak memberikan pengaruh utama terhadap diameter tongkol tetapi data Tabel 6. menunjukkan bahwa tanaman yang ditanam dengan jarak $70 \times 30 \mathrm{~cm}$ menghasilkan tongkol yang cenderung lebih besar dibandingkan tongkol yang dihasilkan dari tanaman yang ditanam dengan jarak $70 \times 40 \mathrm{~cm}$ maupun $70 \times 50 \mathrm{~cm}$.

Tabel 6. Diameter Tongkol $(\mathrm{cm})$

\begin{tabular}{ccccc}
\hline Takaran & \multicolumn{3}{c}{ Jarak Tanam } & \multirow{2}{*}{ Rerata } \\
\cline { 2 - 4 } Pupuk & $70 \times 30$ & $70 \times 40$ & $70 \times 50$ & \\
\hline 0 t/ha & 4,3 & 4,3 & 4,1 & $4,2 \mathrm{~b}$ \\
20 t/ha & 4,5 & 4,3 & 4,4 & $4,4 \mathrm{a}$ \\
25 t/ha & 4,5 & 4,4 & 4,4 & $4,4 \mathrm{a}$ \\
\hline Rerata & $4,4 \mathrm{a}$ & $4,3 \mathrm{a}$ & $4,3 \mathrm{a}$ & $(-)$ \\
\hline Keterangan : & Angka pada baris dan kolom yang diikuti dengan huruf yang sama & & \\
& tidak berbeda nyata menurut uji DMRT $\alpha 5 \%$ & \\
& (-) : Tidak terjadi interaksi antar faktor &
\end{tabular}

\subsection{Jumlah Baris Per Tongkol}

Hasil sidik ragam (Anova) menunjukkan bahwa tidak terjadi pengaruh interaksi antara takaran pupuk kandang babi dan jarak tanam terhadap jumlah baris per tongkol.

Tabel 7. Jumlah Baris Per Tongkol

\begin{tabular}{ccccc}
\hline Takaran & \multicolumn{3}{c}{ Jarak Tanam } & \multirow{2}{*}{ Rerata } \\
\cline { 2 - 4 } Pupuk & $70 \times 30$ & $70 \times 40$ & $70 \times 50$ & \\
\hline $0 \mathrm{t} / \mathrm{ha}$ & 15,3 & 14,5 & 14,1 & $14,6 \mathrm{a}$ \\
$20 \mathrm{t} / \mathrm{ha}$ & 15,7 & 14,9 & 14,5 & $15,0 \mathrm{a}$ \\
$25 \mathrm{t} / \mathrm{ha}$ & 14,8 & 14,6 & 15,0 & $14,8 \mathrm{a}$ \\
\hline Rerata & 15,3 a & $14,6 \mathrm{ab}$ & $14,5 \mathrm{~b}$ & $(-)$ \\
\hline Keterangan : & $\begin{array}{l}\text { Angka pada baris dan kolom yang dikuti dengan huruf } \\
\text { tidak berbeda nyata menurut uji DMRT } \alpha 5 \%\end{array}$ & \\
& $(-)$ : Tidak terjadi interaksi antar faktor &
\end{tabular}

Takaran pupuk kandang babi tidak memberikan pengaruh utama terhadap jumlah baris per tongkol, meskipun demikian, data Tabel 7. menunjukkan bahwa baris setiap tongkol yang dihasilkan dari tanaman yang diberikan pupuk kandang babi dengan takaran 20 t/ha cenderung lebih banyak sedangkan baris setiap tongkol yang dihasilkan dari tanaman yang tidak diberikan pupuk kandang babi paling sedikit.

Jarak tanam memberikan pengaruh utama terhadap jumlah baris per tongkol dimana tanaman yang ditanam dengan jarak 70 × $30 \mathrm{~cm}$ menghasilkan baris dalam setiap tongkol yang paling banyak dan berbeda nyata dengan 
jumlah baris per tongkol yang dihasilkan oleh tanaman yang ditanam dengan jarak $70 \times 50 \mathrm{~cm}$ tetapi tidak berbeda nyata dengan jumlah baris per tongkol yang dihasilkan oleh tanaman yang ditanam dengan jarak 70 x $40 \mathrm{~cm}$.

\subsection{Jumlah Biji Per Baris}

Hasil sidik ragam (Anova) menunjukkan bahwa tidak terjadi pengaruh interaksi antara takaran pupuk kandang babi dan jarak tanam terhadap jumlah biji per baris.

Takaran pupuk kandang babi memberikan pengaruh utama terhadap jumlah biji per baris. Biji dalam setiap baris yang dihasilkan dari tanaman yang diberikan pupuk kandang babi dengan takaran $20 \mathrm{t} / \mathrm{ha}$ paling banyak dan berbeda nyata dengan jumlah biji per baris yang dihasilkan dari tanaman yang tidak diberikan pupuk kandang babi tetapi tidak berbeda nyata dengan jumlah biji per baris yang dihasilkan dari tanaman yang diberikan pupuk kandang babi dengan takaran 25 t/ha. Jarak tanam tidak memberikan pengaruh utama terhadap jumlah biji per baris tetapi data Tabel 8. menunjukkan bahwa tanaman yang ditanam dengan jarak 70 × $30 \mathrm{~cm}$ menghasilkan biji setiap baris yang cenderung lebih banyak sedangkan tanaman yang ditanam dengan jarak 70 x 40 $\mathrm{cm}$ menghasilkan biji setiap barisnya yang paling sedikit.

Tabel 8. Jumlah Biji Per Baris

\begin{tabular}{ccccc}
\hline Takaran & \multicolumn{3}{c}{ Jarak Tanam } & \multirow{2}{*}{ Rerata } \\
\cline { 2 - 4 } Pupuk & $70 \times 30$ & $70 \times 40$ & $70 \times 50$ & \\
\hline 0 t/ha & 19,9 & 22,9 & 21,5 & $21,4 \mathrm{~b}$ \\
20 t/ha & 27,4 & 24,8 & 26,3 & $26,2 \mathrm{a}$ \\
$25 \mathrm{t} / \mathrm{ha}$ & 27,7 & 24,5 & 25,2 & $25,8 \mathrm{a}$ \\
\hline Rerata & $25,0 \mathrm{a}$ & $24,1 \mathrm{a}$ & $24,3 \mathrm{a}$ & $(-)$ \\
\hline Keterangan : & \multicolumn{2}{l}{ Angka pada baris dan kolom yang diikuti dengan huruf } & yang sama \\
& tidak berbeda nyata menurut uji DMRT $\alpha 5 \%$ & \\
& (-) : Tidak terjadi interaksi antar faktor &
\end{tabular}

\subsection{Jumlah Tongkol Per Petak}

Perbedaan populasi dalam setiap petak percobaan karena perbedaan jarak tanam yang digunakan dengan jumlah tongkol setiap tanaman yang sama menyebabkan perbedaan jumlah tongkol per petak yang signifikan antara level jarak tanam. Hasil sidik ragam (Anova) menunjukkan bahwa tidak terjadi pengaruh interaksi antara takaran pupuk kandang babi dan jarak tanam terhadap jumlah tongkol per petak. Takaran pupuk kandang babi juga tidak memberikan pengaruh utama terhadap jumlah tongkol per petak, tetapi jarak tanam memberikan pengaruh utama yang nyata dimana jumlah tongkol setiap petak yang dihasilkan saling berbeda nyata antara jarak tanam yang berbeda. Tanaman yang ditanam dengan jarak 70 x $30 \mathrm{~cm}$ menghasilkan tongkol setiap petak yang paling banyak sedangkan tanaman yang ditanam dengan jarak $70 \mathrm{x}$ $50 \mathrm{~cm}$ menghasilkan tongkol setiap petak yang paling sedikit.

Tabel 9. Jumlah Tongkol Per Petak

\begin{tabular}{ccccc}
\hline Takaran & \multicolumn{3}{c}{ Jarak Tanam } & \multirow{2}{*}{ Rerata } \\
\cline { 2 - 4 } Pupuk & $70 \times 30$ & $70 \times 40$ & $70 \times 50$ & \\
\hline 0 t/ha & 110 & 90 & 70 & $90 \mathrm{a}$ \\
$20 \mathrm{t} / \mathrm{ha}$ & 110 & 90 & 70 & $90 \mathrm{a}$ \\
$25 \mathrm{t} / \mathrm{ha}$ & 110 & 90 & 70 & $90 \mathrm{a}$ \\
\hline Rerata & $110 \mathrm{a}$ & $90 \mathrm{~b}$ & $70 \mathrm{c}$ & $(-)$ \\
\hline Keterangan : & $\begin{array}{l}\text { Angka pada baris dan kolom yang diikuti dengan huruf } \\
\text { tidak berbeda nyata menurut uji DMRT } \alpha 5 \%\end{array}$ & \\
& $(-)$ : Tidak terjadi interaksi antar faktor &
\end{tabular}

\subsection{Berat Pipilan Kering Per Tanaman}

Hasil sidik ragam (Anova) menunjukkan bahwa tidak terjadi pengaruh interaksi antara takaran pupuk kandang babi dan jarak tanam terhadap berat pipilan kering per tanaman. Takaran pupuk kandang babi memberikan pengaruh utama terhadap berat pipilan kering per tanaman dimana pipilan kering yang dihasilkan dari tanaman yang diberikan pupuk kandang babi dengan takaran $25 \mathrm{t} / \mathrm{ha}$ paling berat dan berbeda nyata dengan berat pipilan kering yang dihasilkan dari tanaman yang tidak diberikan pupuk kandang babi tetapi tidak berbeda nyata dengan berat pipilan kering yang dihasilkan dari tanaman yang diberikan pupuk kandang babi dengan takaran $20 \mathrm{t} / \mathrm{ha}$.

Jarak tanam tidak memberikan pengaruh utama terhadap berat pipilan kering per tanaman tetapi data Tabel 10. menunjukkan bahwa tanaman yang ditanam dengan jarak 70 × $30 \mathrm{~cm}$ menghasilkan pipilan kering yang cenderung lebih berat sedangkan tanaman yang ditanam dengan jarak 70 x $40 \mathrm{~cm}$ menghasilkan pipilan kering yang paling ringan.

Tabel 10. Berat Pipilan Kering Per Tanaman (g)

\begin{tabular}{ccccc}
\hline Takaran & \multicolumn{3}{c}{ Jarak Tanam } & \multirow{2}{*}{ Rerata } \\
\cline { 2 - 4 } Pupuk & $70 \times 30$ & $70 \times 40$ & $70 \times 50$ & \\
\hline 0 t/ha & 100,7 & 118,7 & 110,7 & $110,0 \mathrm{~b}$ \\
$20 \mathrm{t} / \mathrm{ha}$ & 136,0 & 118,0 & 142,7 & $132,2 \mathrm{a}$ \\
$25 \mathrm{t} / \mathrm{ha}$ & 162,7 & 124,7 & 134,7 & $140,7 \mathrm{a}$ \\
\hline Rerata & $133,1 \mathrm{a}$ & $120,4 \mathrm{a}$ & $129,3 \mathrm{a}$ & $(-)$ \\
\hline Keterangan : & \multicolumn{2}{|c}{ Angka pada baris dan kolom yang diikuti dengan huruf yang sama } \\
& tidak berbeda nyata menurut uji DMRT $\alpha 5 \%$ & \\
& $(-)$ : Tidak terjadi interaksi antar faktor &
\end{tabular}

\subsection{Berat 100 Biji}

Hasil sidik ragam (Anova) menunjukkan bahwa terjadi pengaruh interaksi antara takaran pupuk kandang babi dan jarak tanam terhadap berat 100 biji dimana 100 biji yang dihasilkan tanaman yang diberikan pupuk kandang babi dengan takaran $20 \mathrm{t} /$ ha dan ditanam dengan jarak 70 x $30 \mathrm{~cm}$ serta tanaman yang diberikan pupuk kandang babi dengan takaran $25 \mathrm{t} / \mathrm{ha}$ dan ditanam dengan jarak $70 \times 40 \mathrm{~cm}$ paling berat dan berbeda nyata dengan berat 100 biji yang dihasilkan tanaman yang tidak diberikan pupuk kandang babi dan ditanam dengan jarak $70 \times 30 \mathrm{~cm}$ serta tanaman yang diberikan pupuk kandang babi dengan takaran 20 t/ha dan ditanam dengan jarak 70 x $50 \mathrm{~cm}$ tetapi tidak berbeda nyata dengan berat 100 biji yang dihasilkan oleh tanaman yang diberikan kombinasi perlakuan yang lainnya.

Takaran pupuk kandang babi dan jarak tanam tidak memberikan pengaruh utama masing-masing perlakuan terhadap berat 100 biji, meskipun demikian data Tabel 11. menunjukkan bahwa 100 biji yang dihasilkan dari tanaman yang diberikan pupuk kandang babi dengan takaran 25 t/ha cenderung lebih berat sedangkan 100 biji yang dihasilkan dari tanaman yang tidak diberikan pupuk kandang babi paling ringan. Tanaman yang ditanam dengan jarak 70 x $40 \mathrm{~cm}$ menghasilkan 100 biji yang cenderung lebih berat sedangkan tanaman yang ditanam dengan jarak 70 x $50 \mathrm{~cm}$ menghasilkan 100 biji yang paling ringan.

Tabel 11. Berat 100 Biji $(\mathrm{g})$

\begin{tabular}{cllll}
\hline Takaran & \multicolumn{3}{c}{ Jarak Tanam } & \multirow{2}{*}{ Rerata } \\
\cline { 2 - 4 } Pupuk & \multicolumn{1}{c}{$70 \times 30$} & $70 \times 40$ & $70 \times 50$ & \\
\hline $0 \mathrm{t} / \mathrm{ha}$ & $24,9 \mathrm{bc}$ & $26,0 \mathrm{abc}$ & $27,4 \mathrm{ab}$ & $26,1 \mathrm{a}$ \\
$20 \mathrm{t} / \mathrm{ha}$ & $28,4 \mathrm{a}$ & $26,3 \mathrm{abc}$ & $24,2 \mathrm{c}$ & $26,3 \mathrm{a}$ \\
$25 \mathrm{t} / \mathrm{ha}$ & $26,4 \mathrm{abc}$ & $28,4 \mathrm{a}$ & $26,2 \mathrm{abc}$ & $27,0 \mathrm{a}$ \\
\hline Rerata & $26,6 \mathrm{a}$ & $26,9 \mathrm{a}$ & $25,9 \mathrm{a}$ & $(+)$ \\
\hline
\end{tabular}

Keterangan: Angka pada baris dan kolom yang diikuti dengan huruf yang sama tidak berbeda nyata menurut uji DMRT $\alpha 5 \%$ $(+)$ : Terjadi interaksi antar faktor

\subsection{Berat Pipilan Kering Per Petak}

Hasil sidik ragam (Anova) menunjukkan bahwa terjadi pengaruh interaksi antara takaran pupuk kandang babi dan jarak tanam terhadap berat pipilan kering per petak dimana pipilan kering setiap petak yang dihasilkan tanaman yang diberikan pupuk kandang babi dengan takaran $25 \mathrm{t} / \mathrm{ha}$ dan ditanam dengan jarak 70 × $30 \mathrm{~cm}$ paling berat dan berbeda nyata dengan berat pipilan kering yang dihasilkan tanaman yang diberikan kombinasi perlakuan yang lainnya kecuali pipilan kering setiap petak yang dihasilkan tanaman yang diberikan pupuk kandang babi dengan takaran 20 t/ha dan ditanam dengan jarak 70 x 30 $\mathrm{cm}$

\begin{tabular}{ccccc}
\multicolumn{6}{c}{ Tabel 12. Berat Pipilan Kering Per Petak (t/ha) } & \multirow{2}{*}{ Rerata } \\
\cline { 2 - 4 } Takaran & \multicolumn{3}{c}{ Jarak Tanam } \\
Pupuk & $70 \times 30$ & $70 \times 40$ & $70 \times 50$ & \\
\hline $0 \mathrm{t} / \mathrm{ha}$ & $2,67 \mathrm{bc}$ & $2,07 \mathrm{~d}$ & $2,10 \mathrm{~d}$ & $2,28 \mathrm{~b}$ \\
$20 \mathrm{t} / \mathrm{ha}$ & $3,48 \mathrm{a}$ & $2,75 \mathrm{~b}$ & $2,15 \mathrm{~d}$ & $2,79 \mathrm{a}$ \\
$25 \mathrm{t} / \mathrm{ha}$ & $3,54 \mathrm{a}$ & $2,83 \mathrm{~b}$ & $2,37 \mathrm{~cd}$ & $2,91 \mathrm{a}$ \\
\hline Rerata & $3,23 \mathrm{a}$ & $2,55 \mathrm{~b}$ & $2,20 \mathrm{c}$ & $(+)$ \\
\hline Keterangan : & Angka pada baris dan kolom yang diikuti dengan huruf & yang sama
\end{tabular}

Keterangan: Angka pada baris dan kolom yang diikuti dengan huruf yang sama tidak berbeda nyata menurut uji DMRT $\alpha 5 \%$ $(+)$ : Terjadi interaksi antar faktor

Takaran pupuk kandang babi dan jarak tanam memberikan pengaruh utama masing-masing perlakuan terhadap berat pipilan kering per petak. Pipilan kering per petak yang dihasilkan dari tanaman yang diberikan pupuk kandang babi dengan takaran $25 \mathrm{t} / \mathrm{ha}$ paling berat dan berbeda nyata dengan berat pipilan kering per petak yang dihasilkan dari tanaman yang tidak diberikan pupuk kandang babi tetapi tidak berbeda nyata dengan berat pipilan kering per petak yang dihasilkan dari tanaman yang diberikan pupuk kandang babi dengan takaran 20 t/ha. Tanaman yang ditanam dengan jarak 70 × $30 \mathrm{~cm}$ menghasilkan pipilan kering per petak yang paling berat dan berbeda nyata dengan berat pipilan kering per petak yang dihasilkan oleh tanaman yang ditanam dengan jarak $70 \times 40 \mathrm{~cm}$ maupun $70 \times 50 \mathrm{~cm}$ yang menghasilkan pipilan kering per petak yang paling ringan.

\subsection{Berat Segar Berangkasan}

Hasil sidik ragam (Anova) menunjukkan bahwa tidak terjadi pengaruh interaksi antara takaran pupuk kandang babi dan jarak tanam terhadap berat segar berangkasan.

Takaran pupuk kandang babi dan jarak tanam memberikan pengaruh utama masing-masing perlakuan terhadap berat segar berangkasan. Berangkasan segar tanaman yang diberikan pupuk kandang babi dengan takaran 25 t/ha paling berat dan berbeda nyata dengan berat segar berangkasan dari tanaman yang diberikan pupuk kandang babi dengan takaran 20 t/ha maupun tanaman yang tidak diberikan pupuk kandang babi yang memiliki berangkasan segar paling ringan. Tanaman yang ditanam dengan jarak $70 \times 30 \mathrm{~cm}$ memiliki berangkasan segar yang paling berat dan berbeda nyata dengan berat segar berangkasan tanaman yang ditanam dengan jarak $70 \times 50 \mathrm{~cm}$ tetapi tidak berbeda nyata dengan berat segar berangkasan tanaman yang ditanam dengan jarak $70 \times 40$ $\mathrm{cm}$. 
Tabel 13. Berat Segar Berangkasan (t/ha)

\begin{tabular}{ccccc}
\hline Takaran & \multicolumn{3}{c}{ Jarak Tanam } & \multirow{2}{*}{ Rerata } \\
\cline { 2 - 4 } Pupuk & $70 \times 30$ & $70 \times 40$ & $70 \times 50$ & \\
\hline 0 t/ha & 6,6 & 6,8 & 5,7 & $6,3 \mathrm{~b}$ \\
$20 \mathrm{t} / \mathrm{ha}$ & 7,2 & 6,5 & 5,9 & $6,5 \mathrm{~b}$ \\
$25 \mathrm{t} / \mathrm{ha}$ & 7,6 & 7,2 & 6,1 & $7,0 \mathrm{a}$ \\
\hline Rerata & $7,1 \mathrm{a}$ & $6,8 \mathrm{a}$ & $5,9 \mathrm{~b}$ & $(-)$ \\
\hline Keterangan : & Angka pada baris dan kolom yang diikuti dengan huruf & yang sama \\
& tidak berbeda nyata menurut uji DMRT $\alpha 5 \%$ & \\
& (-) : Tidak terjadi interaksi antar faktor &
\end{tabular}

\subsection{Berat Kering Berangkasan}

Hasil sidik ragam (Anova) menunjukkan bahwa tidak terjadi pengaruh interaksi antara takaran pupuk kandang babi dan jarak tanam terhadap berat kering berangkasan.

Takaran pupuk kandang babi dan jarak tanam memberikan pengaruh utama masing-masing perlakuan terhadap berat kering berangkasan. Berat kering berangkasan tanaman yang diberikan pupuk kandang babi dengan takaran 25 t/ha paling berat dan berbeda nyata dengan berat kering berangkasan tanaman yang tidak diberikan pupuk kandang babi tetapi tidak berbeda nyata dengan berat kering berangkasan tanaman yang diberikan pupuk kandang babi dengan takaran 20 t/ha. Tanaman yang ditanam dengan jarak 70 x $30 \mathrm{~cm}$ memiliki berangkasan kering yang paling berat dan berbeda nyata dengan berat kering berangkasan tanaman yang ditanam dengan jarak 70 x $50 \mathrm{~cm}$ tetapi tidak berbeda nyata dengan berat kering berangkasan tanaman yang ditanam dengan jarak 70 x $40 \mathrm{~cm}$.

Tabel 14. Berat Kering Berangkasan (t/ha)

\begin{tabular}{ccccc}
\hline Takaran & \multicolumn{3}{c}{ Jarak Tanam } & \multirow{2}{*}{ Rerata } \\
\cline { 2 - 4 } Pupuk & $70 \times 30$ & $70 \times 40$ & $70 \times 50$ & \\
\hline 0 t/ha & 4,1 & 4,3 & 3,8 & $4,1 \mathrm{~b}$ \\
$20 \mathrm{t} / \mathrm{ha}$ & 5,2 & 4,3 & 4,3 & $4,6 \mathrm{a}$ \\
$25 \mathrm{t} / \mathrm{ha}$ & 5,1 & 4,8 & 4,4 & $4,8 \mathrm{a}$ \\
\hline Rerata & $4,8 \mathrm{a}$ & $4,5 \mathrm{ab}$ & $4,2 \mathrm{~b}$ & $(-)$ \\
\hline Keterangan : & Angka pada baris dan kolom yang diikuti dengan huruf yang sama & & \\
& tidak berbeda nyata menurut uji DMRT $\alpha 5 \%$ & \\
& (-) : Tidak terjadi interaksi antar faktor &
\end{tabular}

\subsection{Indeks Panen}

Hasil sidik ragam (Anova) menunjukkan bahwa tidak terjadi pengaruh interaksi antara takaran pupuk kandang babi dan jarak tanam terhadap indeks panen.

Takaran pupuk kandang babi tidak memberikan pengaruh utama terhadap indeks panen, meskipun demikian, data Tabel 15. menunjukkan bahwa indeks panen dari tanaman yang diberikan pupuk kandang babi dengan takaran $25 \mathrm{t} / \mathrm{ha}$ cenderung lebih tinggi sedangkan indeks panen dari tanaman yang tidak diberikan pupuk kandang babi paling rendah. Jarak tanam memberikan pengaruh utama terhadap indeks panen dimana tanaman yang ditanam dengan jarak 70 x $30 \mathrm{~cm}$ memberikan nilai indeks panen yang paling tinggi dan berbeda nyata dengan indeks panen tanaman yang ditanam dengan jarak $70 \mathrm{x}$ $40 \mathrm{~cm}$ maupun dengan jarak 70 x $50 \mathrm{~cm}$ yang memiliki indeks panen terendah.

Tabel 15. Indeks Panen (\%)

\begin{tabular}{ccccc}
\hline Takaran & \multicolumn{3}{c}{ Jarak Tanam } & \multirow{2}{*}{ Rerata } \\
\cline { 2 - 4 } Pupuk & $70 \times 30$ & $70 \times 40$ & $70 \times 50$ & \\
\hline 0 t/ha & 39,0 & 32,7 & 36,1 & $35,9 \mathrm{a}$ \\
$20 \mathrm{t} / \mathrm{ha}$ & 40,1 & 39,1 & 33,2 & $37,5 \mathrm{a}$ \\
$25 \mathrm{t} / \mathrm{ha}$ & 41,1 & 36,8 & 35,3 & $37,7 \mathrm{a}$ \\
\hline Rerata & $40,1 \mathrm{a}$ & $36,2 \mathrm{~b}$ & $34,9 \mathrm{~b}$ & $(-)$ \\
\hline Keterangan : & $\begin{array}{l}\text { Angka pada baris dan kolom yang diikuti dengan huruf } \\
\text { tidak berbeda nyata menurut uji DMRT } \alpha 5 \%\end{array}$ & \\
& (-) : Tidak terjadi interaksi antar faktor &
\end{tabular}

\subsection{Pembahasan}

Pemberian pupuk kandang babi dengan takaran yang paling tinggi yakni 25 t/ha mampu menjamin ketersediaan unsur hara bagi tanaman jagung meski ditanam dengan jarak tanam yang paling rapat yakni 70 x $30 \mathrm{~cm}$. Pengaruh interaksi takaran pupuk kandang babi dan jarak tanam ini mampu memberikan hasil yang tertinggi untuk jagung hibrida Pioner hingga mencapai 3,54 ton setiap hektarnya. Hasil yang cukup tinggi juga $(3,48 \mathrm{t} / \mathrm{ha})$ dan tidak berbeda secara signifikan bisa dicapai dengan menggunakan jarak tanam yang sama tetapi dengan takaran pupuk kandang babi hanya $20 \mathrm{t} / \mathrm{ha}$.

Secara statistik selain berpengaruh pada berat pipilan kering per petak, takaran pupuk kandang babi dan jarak tanam juga memberikan pengaruh interaksi terhadap panjang tongkol dan berat 100 biji, sedangkan pada parameter lainnya takaran pupuk kandang babi dan jarak tanam juga tidak memberikan pengaruh interaksi. Meskipun demikian berdasarkan data-data hasil penelitian yang diuraikan sebelumnya dapat dilihat bahwa kombinasi perlakuan takaran pupuk kandang babi 25 t/ha dengan jarak tanam $70 \times 30 \mathrm{~cm}$ memberikan hasil berupa tongkol yang paling panjang dan besar, walaupun jumlah baris dalam setiap tongkol tidak terlalu banyak tetapi dalam setiap barisnya memiliki biji yang paling banyak sehingga pipilan kering setiap tanamannya paling berat. Walaupun 100 biji tidak terlalu berat tetapi pada akhirnya kombinasi perlakuan ini menghasilkan pipilan kering setiap petak yang paling berat. Indeks panen yang dihasilkan juga paling tinggi.

\section{Simpulan}

Takaran pupuk kandang babi dan jarak tanam memberikan pengaruh interaksi terhadap panjang tongkol, berat 100 biji dan berat pipilan kering per petak. Takaran pupuk kandang babi berpengaruh nyata terhadap luas daun, panjang tongkol, diameter tongkol, jumlah biji per baris, berat pipilan kering per tanaman, berat pipilan kering per petak, berat segar berangkasan dan berat kering berangkasan. Jarak tanam berpengaruh nyata terhadap luas daun, jumlah baris per tongkol, jumlah tongkol per petak, berat pipilan kering per petak, berat segar berangkasan, berat kering berangkasan dan indeks panen. Takaran pupuk kandang babi 25 t/ha dengan jarak tanam $70 \times 30 \mathrm{~cm}$ memberikan hasil jagung tertinggi berupa pipilan kering 3,48 t/ha.

\section{Pustaka}

Ahmed, S.I., Mickelson, S.K., Pederson, C.H., Baker, J.L., Kanwar, R.S., Lorimor, J.C., Webber, D.F., 2013. Swine manure rate, timing, and application method effects on post-harvest soil nutrients, crop yield, and potential water quality implications in a corn-soybean rotation. Trans ASABE 56, 395-408.

BPS RI, 2014. Statistik Indonesia. Badan Pusat Statistik Republik Indonesia, Jakarta.

Dad Resiworo, J.S., 1992. Pengendalian Gulma Dengan Pengaturan Jarak Tanam dan Cara Penyiangan pada Pertanaman Kedelai. Pros. Konf. Himpun. Ilmu Gulma Indones. Ujung Pandang Hal 247-250.

Djajadiningrat, S.T., Harsono, H., 1991. Penilaian Secara Cepat SumberSumber Pencemaranair, Tanah dan Udara. Gadjah Mada University Press, Yogyakarta.

Djakfar, Z.R., Ardi, Suyati, D., Yuliadi, E., Hadiyono, Sjfyan, Y., Aswad, M., Sagiman, S., 1990. Dasar-Dasar Agronomi. BKS-B USIAD, Palembang.

Effendi, S., 2008. Cropping system suatu cara untuk stabilisasi produksi pertanian. Penataran PPS Bid. Agron. Dalam Pola Bertanam Lemb. Penelit. Bogor.

Effendi, S., 1977. Bercocok Tanam Jagung. CV. Yasaguna, Jakarta.

Gomez, K.A., Gomez, A.A., 1984. Statistical Procedures for Agricultural Research. John Wiley \& Sons.

Joses, W., 1997. Teknik Pra Panen dan Pasca Panen. ITB Press, Bandung.

Kusuma, M.E., 2012. Pengaruh Beberapa Jenis Pupuk Kandang Terhadap Kualitas Bokashi. J. Trop. Anim. Sci. 1, 41-46.

Lingga, P., Marsono, 2001. Petunjuk Penggunaan Pupuk. Penebar Swadaya, Jakarta.

Marzuki, R., 2002. Bertanam Jagung Manis. Penebar Swadaya, Jakarta.

Pingali, P.L., 2001. CIMMYT 1999/2000 World maize facts and trends. Meeting world maize needs: Technological opportunities and priorities for the public sector.

Purwono, Hartono, 2008. Bertanam Jagung Unggul. Penebar Swadaya, Jakarta.

Rukmana, R., 1997. Usaha Tani Jagung. Kanisius, Yogyakarta.

Waluya, A., 2009. Gulma pada tanaman jagung di Kebun Percobaan Cikabayan, Institut Pertanian Bogor. Penguasaan Sarana Tumbuh Dep. Agron. Dan Hortik. Inst. Pertan. Bogor.

Warisno, 1998. Jagung Hibrida. Kanisius, Yogyakarta.

Yahya, S., Chozin, M.A., others, 2005. Kompetisi Tanaman Jagung dan Ubikayu dalam Sistem Tumpang Sari. J. Agron. Indones. Indones. J. Agron. 33. 